\title{
Particulate phase emission of parent polycyclic aromatic hydrocarbons (PAHs) and their derivatives (alkyl-PAHs, oxygenated-PAHs, azaarenes and nitrated PAHs) from manually and automatically fired combustion appliances
}

\author{
Estela Domingos Vicente ${ }^{1}$ - Ana M. Vicente ${ }^{1} \cdot$ Benjamin A. Musa Bandowe $^{2}$. $^{-}$ \\ Célia A. Alves 1
}

Received: 12 May 2015 / Accepted: 10 July 2015 / Published online: 26 July 2015

(C) Springer Science+Business Media Dordrecht 2015

\begin{abstract}
Residential biomass combustion may represent a significant emission source of polycyclic aromatic hydrocarbons (PAHs) and derivatives, some of which are known for their toxicity. In this study, a manually operated batch stove (burning wood logs) and an automatic pellet stove were selected to carry out combustion experiments. Two types of firewood (pine and eucalypt) were used as fuels in the manual stove. Four types of pellets and three agricultural fuels (olive pit, almond shell and shell of pine nuts) were selected for the automatic stove. The particulate matter $\left(\mathrm{PM}_{10}\right)$ samples from the exhaust flue gas were solvent extracted and analysed for 26 parent and alkyl-PAHs, 15 nitrated PAHs (NPAHs), 15 oxygenated PAHs (OPAHs) and 4 azaarenes (AZAs) by gas chromatography-mass spectrometry. The global parent PAH emission factors (EFs) for the pellet stove ranged from 0.046 to $0.51 \mathrm{mg} \mathrm{kg}^{-1}$ of fuel burned, dry basis (db). The EFs obtained for the manual stove varied from 0.33 to 1.97 and from 8.65 to $24.3 \mathrm{mg} \mathrm{kg}^{-1}$ (db) for the combustion of eucalypt and pine, respectively. The devolatilisation phase of softwood in the latter appliance is critical because benzo[a]pyrene emissions can be more than 1,000 times higher than the values observed for any other combustion stages, appliance or
\end{abstract}

Electronic supplementary material The online version of this article (doi:10.1007/s11869-015-0364-1) contains supplementary material, which is available to authorized users.

Célia A. Alves

celia.alves@ua.pt

1 Centre for Environmental and Marine Studies, Department of Environment and Planning, University of Aveiro,

3810-193 Aveiro, Portugal

2 Institute of Geography, University of Bern, Hallerstrasse 12, 3012 Bern, Switzerland biofuels. As for parent PAHs, it was observed that emissions of OPAHs, NPAHs and AZAs vary greatly depending on either the biofuel or the combustion technology.

Keywords PAHs $\cdot$ Oxygenated PAHs $\cdot$ Nitrated PAHs · Azaarenes $\cdot \mathrm{PM}_{10} \cdot$ Residential biomass combustion

\section{Introduction}

The $\mathrm{PM}_{10}$ daily limit value $\left(50 \mu \mathrm{g} \mathrm{m}^{-3}\right.$, not to be exceeded more than 35 times in a year) is often surpassed in many regions across Europe, including Portugal (Monteiro et al. 2007). During winter time, these exceedances are often associated with residential wood combustion (RWC; Waked et al. 2014; Bressi et al. 2014; Reche et al. 2012; Bernardoni et al. 2011). The health effects caused by the inhalation of particles are not only related to their size, but also with their chemical composition (Huang et al. 2012; Lippmann 2012; Ostro et al. 2008). The organic fraction of particles released from RWC encompasses a wide range of substances, for example, mutagenic compounds, such as PAHs and their derivatives (Claxton et al. 2004; Oanh et al. 2002). Emissions from RWC are mainly composed of submicron particles (Pettersson et al. 2011; Tissari et al. 2008), which have greater percentages of extractable organic material and mutagenic compounds than the larger ones (Claxton et al. 2004). Albinet et al. (2008) reported that around 60 to $90 \%$ of the PAHs, oxygenated PAHs (OPAHs) and nitrated PAHs (NPAHs), in an Alpine valley highly impacted by combustion processes, were associated with fine particles. Several studies have focused on these compounds not only because of their ubiquitous presence in the environment, but also because they are known to be immunotoxic, carcinogenic and mutagenic 
(White et al. 1994; Durant et al. 1996). The number of benzene rings in the structure of the PAHs determines their carcinogenity (Boström et al. 2002).

In Portugal, it has been estimated that RWC for heating or cooking purposes is responsible for approximately $6.5 \%$ of the national total emissions of PAHs (Gonçalves et al. 2012). Belis et al. (2011) conducted a study in 2007 and 2009 at ten air quality monitoring stations in the North Italian Po Plain and Valtelline Valley. The authors reported that emissions from biomass burning accounted from $74 \pm 32$ to $85 \pm 33 \%$ of all benzo[a]pyrene sources. Zhang et al. (2009) evaluated the lung cancer risk for the Chinese population caused by inhalation of PAHs. It was found that the fraction of lung cancer in the overall population attributable to inhalation of PAHs was $1.6 \%$. Along with parent-PAH, OPAH and NPAH emissions have also been reported in RWC processes (Shen et al. 2012b, 2013a; Orasche et al. 2012). In northern Thailand, it was found that agricultural burning and forest fires are major sources of PAHs and NPAHs in the dry season. Thus, it has been suggested that it is important to control biomass burning to reduce air-pollution-related health risks (Chuesaard et al. 2014).

$\mathrm{Vu}$ et al. (2012) tested the mutagenicity of PAHs (using the Ames test with Salmonella typhimurium strains TA98 and TA100) that were extracted from $\mathrm{PM}_{2.5}$ collected during the combustion of seven wood species and briquettes in a fireplace and a wood stove. A direct mutagenic response was recorded for almost all wood species. Start-up combustion conditions and the fireplace were found to favour the occurrence of mutagenic emissions. Oxygenated PAHs are considered to be more toxic than their parent PAHs because of their direct mutagenic and carcinogenic potency ( $\mathrm{Yu}$ 2002; Pedersen et al. 2004). Some nitrated PAH have also been suggested to be more mutagenic and carcinogenic than unsubstituted PAHs and have been pointed out as directacting genotoxicants (Oanh et al. 2002). N-heterocyclic aromatic compounds, such as azaarenes (AZAs), revealed significant in vitro toxicities (Sovadinová et al. 2006). The Mutatox ${ }^{\mathrm{TM}}$ test showed quinoline to be directly genotoxic and acridine directly mutagenic. The same test has also shown direct genotoxicity of other benzoquinolines such as benzo[h]quinoline (Bleeker et al. 1999). In general, homocyclic PAHs are more toxic than their N-heterocyclic analogues, but AZAs are often more soluble in water, which may imply a greater biological significance of these heterocycles (Bleeker et al. 2002).

The mass of particles emitted from RWC, as well as their composition, are dependent on the combustion technology, fuel quality and operating conditions (e.g. Alves et al. 2011; Gonçalves et al. 2010; Leskinen et al. 2014; Vicente et al. 2015a). The combustion conditions may exert a great influence on particle-bound PAH emissions (Johansson et al. 2004; Lamberg et al. 2011; Orasche et al. 2012). PAH EFs from residential wood and crop straw combustion are affected by the fuel moisture content and modified combustion efficiency. Other important factors are the oxygen supply and burning rates ( $\mathrm{Lu}$ et al. 2009; Shen et al. 2013a, c). Leskinen et al. (2014) studied three different combustion conditions, namely efficient, intermediate and smouldering combustion conditions. The lowest and highest PAH emissions have been, respectively, reported for efficient and smouldering combustion conditions. However, it was also observed that the proportion of genotoxic PAHs was higher in emissions from efficient combustion conditions.

In this study, 26 parent-PAHs, 15 NPAHs, 15 OPAHs and 4 AZAs were quantified in the particulate matter emissions from two residential combustion appliances (manual versus automatic feeding) and nine different fuels. Complementary information on gaseous compounds, such as carbon monoxide $(\mathrm{CO})$, methane $\left(\mathrm{CH}_{4}\right)$, formaldehyde $(\mathrm{HCHO})$ and total organic carbon (TOC) emissions from the pellet stove can be found in Vicente et al. (2015b). This latter manuscript also discusses the carbonaceous content of $\mathrm{PM}_{10}$ samples, as well as their anhydrosugar and elemental composition.

\section{Materials and methods}

\section{Combustion appliances and ancillary instrumentation}

To carry out the combustion experiments, a manually fed wood stove and an automatic pellet stove were selected (Figure S1, supplementary material). The batch-operated wood stove represents the heating device most widely used by householders in Portugal (Gonçalves et al. 2012), whilst the automatic pellet stove is the appliance whose market share has risen more sharply than any other over the last few years.

The top-feed pellet stove (Solzaima, model Alpes, $9.5 \mathrm{~kW}$ nominal output) has an internal pellet storage tank. The fuel is supplied by an auger screw to the burner. The primary combustion air is supplied through holes in the bottom of the basket, while the secondary air is fed at the flame level. The ignition of the fuel is made through an electrical resistance located on the basket of the stove. The burner has a short ash cleaning period programmed to occur during which the fuel supply decreases and the air supply increases for a few minutes. The feeding rate for each fuel was evaluated by prior calibration of the screw feeding system.

The manually loaded stove has a power output of 9.6$18.2 \mathrm{~kW}$ (Solzaima, model Sahara). This typical stove has a manual control of combustion air that enters below the grate. The flow rate of primary air entering in the combustion chamber was monitored by a mass flow meter (Kurz Model: 500-40 $0.0 \mathrm{P}-2)$ located in the ash collection hopper. This model was designed with the same cross section of the stove's air intake to ensure an air flow identical to that originally fed in under 
the grate. This latter was placed above a weight sensor (DSEUROPE Model 535QD-A5) aiming at allowing the continuous monitoring of the fuel mass. For both appliances, the combustion flue gas temperature was monitored using K-type thermocouples at several locations along the system. A detailed description of the combustion facility can be found elsewhere (Calvo et al. 2014; Vicente et al. 2015a, b).

\section{Fuels}

Two types of firewood, Pinus pinaster (maritime pine) and Eucalyptus globulus (eucalypt), a softwood and a hardwood, respectively, were used for feeding the manual appliance. These wood types were selected since they represent the most prevalent tree species in Portugal according to the National Forest Inventory (ICNF 2013) and also for their large market share in the country. Table 1 summarises the main characteristics of the woods whose emissions have been studied. The heating value of these species can be found in the study by Telmo and Lousada (2011).

Four types of pellets were selected for the experiments in the automatic stove. Pellets type I were EN-Plus-labelled commercial wood pellets made mostly of pine wood. Pellets type II were mainly composed of lignocellulosic residues (75\%) and, to a minor extent, of dust from the furniture manufacturing industry (25\%). Pellets type III were composed of the same materials, but in different proportions (blend of $65 \%$ of lignocellulosic residues and $35 \%$ of dust from the furniture manufacturing industry). Pellets type IV were made with a mixture of $50 \%$ of waste woodchips and $50 \%$ of dust from the furniture manufacturing industry. The use of agricultural residues, like olive pit and almond shell, as an energy source has been promoted in some countries, especially in Spain, as part of the 2004-2012 Energy Plan. In Portugal, Spain and other southern European countries, the cork and olive oil sectors generate large amounts of residues that can be used as fuel in small scale appliances (Garcia-Maraver et al. 2014). Thus, three agricultural residues were selected (olive pit, almond shell and shell of pine nuts) to be combusted in the pellet stove. The lower heating value (LHV) ranged from 18.4 (almond shell) to 18.7 (shell of pine nuts) for the agricultural fuels and from 14.4 (pellets type III) to 18.3 (pellets type I) for the pellets. The determination of LHV was performed in accordance with CEN/TS 14918. The determination of the ash and moisture contents was performed following the methodologies defined in CEN/TS 14775 and CEN 14774-3, respectively.

\section{Combustion experiments}

To mimic the user behaviour, the combustion cycle in the wood stove was started at ambient temperature by loading a batch of fuel $(\sim 2 \mathrm{~kg})$ on the grate where two pine-cones had been placed to promote ignition. The air regulation valve was kept completely open throughout the combustion cycle. The subsequent combustion cycles were initiated by putting a batch of fuel $(\sim 2 \mathrm{~kg})$ on a bed of hot charcoal when the temperatures in the combustion chamber were around $100{ }^{\circ} \mathrm{C}$ $\left( \pm 20^{\circ} \mathrm{C}\right)$ and $\mathrm{CO}_{2}$ concentrations in the flue gases reached $4 \%$. At the end of the combustion cycle the mass of charcoal on the grate was less than $10 \%$ of the initial mass of the batch of fuel. The first batch, i.e. initial cold start of each experiment (kindling phase) was not included in this study. After the cold start-up experiment, three combustion cycles were carried out for each wood. Each combustion cycle lasted from 45 to $60 \mathrm{~min}$, depending on the fuel. The temperatures in the combustion chamber were in the range from 390 to $440{ }^{\circ} \mathrm{C}$. An extensive characterisation of operating conditions of the wood stove (temperature profiles, fuel consumption rates in the different phases of the combustion process, flue gas composition etc.) can be found elsewhere (Calvo et al. 2014).

The pellet stove was operated at three levels of power output, in order to cover different behaviours by users (lowest, medium and highest). Each one of the experiments was performed after a preheating period of about $40 \mathrm{~min}$ to ensure that the combustion process had attained a steady operation

Table 1 Elemental composition (db), ash and moisture content of biofuels (wt $\%$ )

\begin{tabular}{|c|c|c|c|c|c|c|c|c|c|c|}
\hline & & $\begin{array}{l}\text { Pellets } \\
\text { type I }\end{array}$ & $\begin{array}{l}\text { Pellets } \\
\text { type II }\end{array}$ & $\begin{array}{l}\text { Pellets } \\
\text { type III }\end{array}$ & $\begin{array}{l}\text { Pellets } \\
\text { type IV }\end{array}$ & $\begin{array}{l}\text { Olive } \\
\text { pit }\end{array}$ & $\begin{array}{l}\text { Shell of pine } \\
\text { nuts }\end{array}$ & $\begin{array}{l}\text { Almond } \\
\text { shell }\end{array}$ & Eucalypt & Pine \\
\hline $\begin{array}{l}\text { Proximate analysis } \\
\text { (wt } \% \text {, as received })\end{array}$ & Moisture & 8.4 & 8.8 & 10.9 & 10.7 & 12.9 & 12.9 & 9.5 & 11.3 & 9.9 \\
\hline \multirow[t]{6}{*}{ Ultimate analysis $(w t \%, d b)$} & Ash & 0.73 & 3.2 & 3.8 & 2 & 0.66 & 1.3 & 1.4 & 0.75 & 0.4 \\
\hline & $\mathrm{C}$ & 49.7 & 47.4 & 48.3 & 47.4 & 50.9 & 49.8 & 49.3 & 48.6 & 51.4 \\
\hline & $\mathrm{H}$ & 6.9 & 6.58 & 6.53 & 6.79 & 6.59 & 6.59 & 6.76 & 6.2 & 6.2 \\
\hline & $\mathrm{N}$ & 0.16 & 2.31 & 2.06 & 2.11 & 0.21 & 0.3 & 0.34 & 0.16 & 0.16 \\
\hline & $\mathrm{S}$ & $<0.01$ & $<0.01$ & $<0.01$ & $<0.01$ & $<0.01$ & $<0.01$ & $<0.01$ & $<0.01$ & $<0.01$ \\
\hline & O (by difference) & 42.5 & 40.5 & 39.3 & 41.7 & 41.6 & 42 & 42 & 44.3 & 41.84 \\
\hline
\end{tabular}


condition. The ignition phase and preheating period were not included in the results. The distinct biofuels were combusted at each level of power output for about $1 \mathrm{~h}$, under steady state operation. The temperatures in the combustion chamber were in the range from 620 to $880{ }^{\circ} \mathrm{C}$, depending on the fuel used and level of power output selected.

The combustion conditions during the experiments in both combustion appliances are displayed in Table 2. It gives information on number of experiments with each fuel, average rate of fuel conversion, average values of the combustion chamber temperatures, $\mathrm{O}_{2}$ concentration in the exit flue gas and $\mathrm{CO}$ EFs.

\section{$\mathbf{P M}_{10}$ sampling}

Particulate matter $\left(\mathrm{PM}_{10}\right)$ was collected in a dilution tunnel $(0.20 \mathrm{~m}$ internal diameter and a length of $11 \mathrm{~m})$ connected to the exhaust stack under isokinetic conditions (Calvo et al. 2014; Vicente et al. 2015a) by a Gent sampler operating at a flow rate of around $12.4 \mathrm{~L} \mathrm{~min}^{-1}$ onto Teflon membrane filters (47 mm diameter, Pall Corporation). The sampling train also included a Teflon-lined diaphragm pump connected to a needle valve and a mass flow controller. The dilution tunnel enables to simulate the rapid cooling and mixing that occurs when the exhaust gases are released into the atmosphere. The dilution of the exhaust gases promotes the temperature decrease and the lowering of vapour pressures of the gaseous species. The decrease of the temperature affects gas to particle partitioning and the net effect is the increased condensation of vapours on particle surface. Thus, the gas to particle partitioning of parent-PAHs and their derivatives depends on their molecular weight and vapour pressure. When the exhaust gases are hot and undiluted, semi-volatiles are almost totally in the gas phase (Boman et al. 2005; Hytonen et al. 2009).

For each combustion experiment in the wood stove, the filters were replaced twice. The first filter was left during approximately $10 \mathrm{~min}$ after loading a batch of fuel on the glowing embers of the preceding cycle. The filter was replaced when the $\mathrm{O}_{2}$ content in the flue gas started to drop. This period corresponded to the initial heating and wood drying and the initial steps of devolatilisation without the existence of a visible flame. The second filter was left for the remaining duration of the combustion cycle, i.e. the flaming and smouldering phases. Each filter was analysed separately in order to evaluate the emissions from both combustion stages. Since each filter replacement took less than $1 \mathrm{~min}$, the overall particle emission factor for each combustion cycle was not considered to be significantly affected. $\mathrm{PM}_{10}$ emissions from the pellet stove were sampled under steady state operating conditions, which were evaluated by continuous monitoring of flue gas composition. The sampling time of each filter was around $1 \mathrm{~h}$. The gravimetric quantification was performed with a microbalance (RADWAG $5 / 2 \mathrm{Y} / \mathrm{F}$ with an accuracy of $1 \mu \mathrm{g}$ ).

\section{PAH, OPAH, AZA and NPAH analyses}

In this study, 26 parent and alkyl-PAHs, 15 OPAHs, 4 AZAs and 15 NPAHs were quantified in all samples and blanks. The list of compounds is displayed in Table 3 . The limits of detection (LOD) for all polycyclic aromatic compounds can be found in Table S2 (Supplementary material). Filters collected for the different power levels of the pellet stove were combined and extracted together in order to obtain "mean" values for each biofuel. This strategy ensures obtaining masses high enough to be able to detect many compounds above their detection limits. $\mathrm{PM}_{10}$ samples from the various replicate experiments in the wood stove were combined according to the combustion phase, i.e. one batch of filters for the devolatilisation stage and another batch for the subsequent flaming and smouldering stages. The filters were placed in $33 \mathrm{~mL}$ extraction cells and spiked with a mixture of 7 deuterated-PAHs (naphthalene-D8, acenaphthene-D10, phenanthrene-D10, pyrene-D10, chrysene-D12, perylene-D12 and

Table 2 Combustion experiments and conditions

\begin{tabular}{lllllll}
\hline $\begin{array}{l}\text { Combustion } \\
\text { appliance }\end{array}$ & Fuel & $\begin{array}{l}\text { Number of } \\
\text { experiments }\end{array}$ & $\begin{array}{l}\text { Rate of fuel } \\
\text { consumption } \\
\left(\mathrm{kg} \mathrm{h}^{-1}\right)\end{array}$ & $\begin{array}{l}\text { Flue gas temperature } \\
\left({ }^{\circ} \mathrm{C}\right) \text { in the combustion } \\
\text { chamber }\end{array}$ & $\begin{array}{l}\mathrm{O}_{2} \text { concentration } \\
(\% \text { v, dry gases }) \\
\text { in the exit flue gas }\end{array}$ & $\begin{array}{l}\text { CO EF } \\
\left(\mathrm{g} \mathrm{kg} \mathrm{k}^{-1} \text { fuel burned, db) }\right.\end{array}$ \\
\hline Pellet stove & Pellets type I & 4 & $1.18 \pm 0.17$ & $683 \pm 49$ & $16.9 \pm 1.3$ & $13.6 \pm 2.29$ \\
& Pellets type II & 9 & $1.40 \pm 0.23$ & $681 \pm 43$ & $16.6 \pm 0.39$ & $2.63 \pm 1.04$ \\
& Pellets type III & 7 & $1.12 \pm 0.17$ & $743 \pm 10$ & $18.2 \pm 0.26$ & $5.22 \pm 0.84$ \\
& Pellets type IV & 6 & $1.44 \pm 0.10$ & $800 \pm 3.1$ & $17.0 \pm 0.33$ & $1.62 \pm 0.34$ \\
& Olive Pit & 6 & $0.88 \pm 0.07$ & $828 \pm 57$ & $18.4 \pm 0.17$ & $27.3 \pm 2.31$ \\
& Shell of Pine Nuts & 8 & $0.96 \pm 0.18$ & $623 \pm 49$ & $17.2 \pm 0.42$ & $13.7 \pm 5.68$ \\
& Almond Shell & 6 & $1.36 \pm 0.29$ & $876 \pm 34$ & $15.7 \pm 1.3$ & $16.9 \pm 4.12$ \\
Wood stove & Eucalypt & 3 & $1.81 \pm 0.28$ & $425 \pm 31$ & $16.8 \pm 0.48$ & $62.9 \pm 4.90$ \\
& Pine & 3 & $2.10 \pm 0.20$ & $390 \pm 42$ & $45.0 \pm 12.1$ \\
\hline
\end{tabular}


Table 3 List of the polycyclic aromatic compounds (PACs) measured in the present study and respective abbreviations

\begin{tabular}{|c|c|c|c|}
\hline PACs & Abbreviation & PACs & Abbreviation \\
\hline Alkyl+parent-PAHs & & OPAHs & \\
\hline 1,2,3,4-Tetrahydronaphthalene & TH-NAP & 1-Indanone & 1-IND \\
\hline Naphthalene & NAP & 1,4-Naphthoquinone & $1,4-\mathrm{NQ}$ \\
\hline 2-Methylnaphthalene & 2-MNAP & 9-Fluorenone & 9-FLU \\
\hline 1-Methylnaphthalene & 1-MNAP & 1,2-Acenaphthylenequinone & 1,2-ACQ \\
\hline Biphenyl & BiPHEN & 9,10-Anthraquinone & 9,10-ANQ \\
\hline 1,3-Dimethylnaphthalene & 1,3-DMNAP & 1,8-Naphthalic anhydride & 1,8-NANH \\
\hline Acenaphthylene & $\mathrm{ACY}$ & 4H-Cyclopenta[d,e,f]phenanthrenone & CpPHEone \\
\hline Acenaphthene & $\mathrm{AC}$ & 2-Methylanthracene-9,10-dione & 2-MANQ \\
\hline Fluorene & FLO & Benzo[a]fluorenone & BaFLU \\
\hline Phenanthrene & PHE & 7H-Benz[d,e]anthracene-7-one & BANTone \\
\hline Anthracene & ANT & Naphthacene-5,12-dione & 5,12-NACQ \\
\hline Cyclopenta[d,e,f]phenanthrene & CPHEN & 6H-benzo[c,d]pyrene-6-one & BPYRone \\
\hline 3,6-Dimethylphenanthrene & 3,6-DMPHE & 1-Naphthaldehyde & 1-NALD \\
\hline Fluoranthene & FLT & 2-Biphenylcarboxaldehyde & 2-BPCA \\
\hline Pyrene & PYR & Benz[a]anthracene-7,12-dione & BANTdione \\
\hline Retene & RET & NPAHs & \\
\hline Benzo[a]anthracene & $\mathrm{BaA}$ & 1-Nitronaphthalene & 1-NitroNAPH \\
\hline Chrysene + Triphenylene & $\mathrm{CHR}+\mathrm{TRY}$ & 2-Nitrobiphenyl & 2-NitroBP \\
\hline Benzo $[\mathrm{b}, \mathrm{j}, \mathrm{k}]$ fluoranthene & BbjkF & 5-Nitroacenaphthene & 5-NitroACEN \\
\hline Benzo[e]pyrene & $\mathrm{BeP}$ & 2-Nitrofluorene & 2-NitroFLUO \\
\hline Benzo[a]pyrene & $\mathrm{BaP}$ & 9-Nitroanthracene & 9-NitroANTH \\
\hline Perylene & PER & 9-Nitrophenanthrene & 9-NitroPHEN \\
\hline Indeno[1,2,3-c,d]pyrene & IcdP & 3-Nitrofluoranthene & 3-NitroFLUA \\
\hline Dibenzo[a,h]anthracene & DahA & 1-Nitropyrene & 1-NitroPYR \\
\hline Benzo[g,h,i]perylene & BghiP & 2,7-Dinitrofluorene & 2,7-DNitroFLUO \\
\hline Coronene & $\mathrm{COR}$ & 6-Nitrochrysene & 6-NitroCHRY \\
\hline AZAs & & 3-Nitrobenzanthrone & 3-NitroBANTone \\
\hline Quinoline & QUI & 1,3-Dinitropyrene & 1,3-DNitroPYR \\
\hline Benzo[h]quinoline & BQI & 1,6-Dinitropyrene & 1,6-DNitroPYR \\
\hline Acridine & ACR & 1,8-Dinitropyrene & 1,8-DNitroPYR \\
\hline Carbazole & $\mathrm{CBZ}$ & 6-Nitrobenzo[a]pyrene & 6-NitroB(A)P \\
\hline
\end{tabular}

benzo[ghi]perylene-D12), 2 deuterated oxy-PAHs (benzophenone-D5 and 9,10-anthraquinone-D8) and 4 deuterated nitroPAHs (1-nitronaphthalene-D7, 2-nitrofluorene-D9, 3nitrofluoranthene-D9 and 6-nitrochrysene-D11) as internal standards for the parent-PAHs, OPAHs and NPAHs, respectively. The extra space in the extraction cell was filled with diatomaceous earth. Each filter was extracted two times by pressurised liquid extraction with an accelerated solvent extractor (ASE 200; Dionex, Sunnyvale, CA). The first extraction was performed with dichloromethane, and the second one with acetone-dichloromethane $(2: 1 \mathrm{v} / \mathrm{v})$. The two extracts from each sample were combined and filtered through sodium sulphate. The combined extract was spiked with hexane, then concentrated to a volume $<1 \mathrm{~mL}$ using a Turbo Vap ${ }^{\circledR}$ II concentrator (Biotage, Charlotte, NC, USA). Each concentrated sample was then transferred onto silica gel (10\% deactivated) columns and fractionated using solvents of different polarity. The following solvents were used to elute the different PAC groups: (1) $15 \mathrm{~mL}$ hexane-dichloromethane (5:1 v/v; parent-PAHs) and (2) $8 \mathrm{~mL}$ dichloromethane followed by $5 \mathrm{~mL}$ acetone (OPAHs and NPAHs). After elution, three drops of toluene were added to each fraction, concentrated to about $0.5 \mathrm{~mL}$, spiked with fluoranthene- $\mathrm{D}_{10}$ (as recovery standard) and transferred to a $1.5 \mathrm{~mL}$ vial. Target compounds in extracts were analysed by gas chromatography-mass spectrometry (GC-MS) using an Agilent $7890 \mathrm{~N}$ gas chromatograph coupled to an Agilent $5975 \mathrm{C}$ inert mass selective detector operating in the electron impact (EI) mode for parent-PAHs and OPAHs, and in the negative chemical ionisation (CI) mode for NPAHs. The instrument was equipped with a HP$5 \mathrm{MS}(30 \mathrm{~m} \times 0.25 \mathrm{~mm} \times 0.25 \mu \mathrm{m})$ column. The analytical procedures for the determination of target compounds were 
described in detail by Bandowe and Wilcke (2010) and Bandowe et al. (2014).

\section{Data analysis}

The emission factor for a chemical species $i$ was calculated according to Equation 1, in which $E F_{i}, \Delta t=$ emission factor of the compound $i$ in grams per kilogram fuel, dry basis, in the sampling interval $\Delta t$ (corresponding to a sampled filter), $C_{i}=$ concentration of the compound $i$ in the flue gas in the dilution tunnel $\left(\mathrm{g} \mathrm{Nm}^{-3}\right), Q_{t, N}=$ mean flue gas flow rate $\left(\mathrm{Nm}^{3} \mathrm{~s}^{-1}\right)$ in the dilution tunnel during the sampling interval, $\Delta t=$ sampling time interval (s) for a filter and $\Delta m=$ mass of fuel consumed (dry basis) during the sampling interval $(\mathrm{kg})$.

$E F_{i}, \Delta t=\frac{C i^{*} \Delta t^{*} Q_{t, N}}{\Delta m}$

The volumetric gas flow rate throughout the tunnel $\left(Q_{\mathrm{t}}, \mathrm{m}^{3} \mathrm{~s}^{-1}\right)$ was calculated from the mean gas velocity $v_{G}\left(\mathrm{~m} \mathrm{~s}^{-1}\right)$ in the cross section of the dilution tunnel $A\left(\mathrm{~m}^{2}\right)$. This mean gas velocity was estimated from the differential pressure monitored by a Pitot tube and respective pressure sensor (Testo AG 808) and a K-type thermocouple.

$Q_{t}=v_{G} * A$

$Q_{t, N}=\frac{Q_{t} * \mathrm{P}_{\mathrm{ref}} * T_{1}}{P_{t}^{*} T_{r e f}}$

where

$T_{1} \quad$ temperature in the dilution tunnel $(\mathrm{K})$

$P_{1}$ pressure in the dilution tunnel $(\mathrm{Pa})$.

Since replicate filters were combined and extracted together, in order to estimate a global EF, a weighted mean was calculated, considering as weighting factor the biomass consumed during the interval of time in which each filter was sampled. For the calculation of PAHs and their derivatives, blank filters were analysed simultaneously in the batches of their respective filter samples and the corresponding blank concentrations were subtracted from the masses of polyaromatic compounds. The $\mathrm{PM}_{10} \mathrm{EFs}$ were calculated by subtracting the average of several blanks from measured values.

\section{Results and discussion}

\section{$\mathbf{P M}_{10}$ emissions}

$\mathrm{PM}_{10}$ EFs from the combustion experiments are presented in Fig. 1. For the pellet stove, the EFs ranged from $0.49 \pm 0.06$ (pellets type I) to $3.12 \pm 0.44$ (olive pit) $\mathrm{g} \mathrm{kg}^{-1}$ of fuel burned (db). The $t$ test revealed that the $\mathrm{PM}_{10}$ EFs from pellets type I and olive pit are significantly different $(\alpha=0.05)$ from each other $(p<0.0001)$. During combustion in more sophisticated appliances, such as pellet stoves, the fuel composition is of great importance, since the PM emissions are almost entirely ash-related material. Pellets type II, III and IV generated higher emission factors (2.8 to 3.6-fold higher) than pellets type I. The difference between the $\mathrm{PM}_{10}$ EF recorded for pellets type I and the other types of pellets (II, III and IV) was statistically significant $(p<0.0001)$. These pellets were made of recycled wood products, wood waste and wood residues, especially from the furniture manufacturing industry. The inclusion of wastes from preservative-treated wood in wood pellets leads to heavy metal emissions, promoting the formation of inorganic aerosols through nucleation and condensation of the ash forming vapours (Obaidullah et al. 2012). The $\mathrm{PM}_{10}$ EFs were found to correlate linearly with the total ash content of the pellets $\left(R^{2}=0.92\right)$. For the agricultural fuels this correlation was not observed. Olive pit was the agricultural fuel with the lowest ash content and highest $\mathrm{PM}_{10} \mathrm{EF}$. Although the ash content of agro-residues were not the highest among all fuels, their higher moisture content as well as the irregular fuel particle size may have affected the biomass feeding rate, which, in turn, may have influenced the appliance performance and its emissions.

$\mathrm{PM}_{10}$ emission factors from the combustion in the traditional wood stove were in the range of $3.81 \pm 2.04$ (eucalypt) to $5.89 \pm 2.17$ (pine) $\mathrm{g} \mathrm{kg}^{-1}$ of fuel burned (db). An insignificant difference $(\alpha=0.05)$ was found between EFs of both fuels ( $p=$ 0.2930 ). Particle emissions from the wood stove were about 3 to 14-fold higher than those from the pellet stove. The highest emissions were recorded during the devolatilisation combustion phase, although it only lasts for around $10 \mathrm{~min}$.

The comparison of emissions obtained in the present study to those described in the literature showed significant differences between traditional residential appliances versus modern stoves with higher combustion efficiency. For example, Fernandes et al. (2011) tested different combustion appliances and reported that the emissions from a traditional wood stove were about 4.5 times higher than those of a more modern wood combustion batch-wise operated appliance.

Emissions resulting from the combustion in automatically fired appliances are significantly lower than those from traditional wood stoves and fireplaces. However, when operating these appliances, variations can be observed (e.g. Schmidl et al. 2008). The fuel properties and the burning mode can exert a great influence on emissions and their chemical composition (e.g. Schmidl et al. 2008; Sippula et al. 2007).

\section{Parent and alkyl-PAHs}

The emissions of PAHs varied considerably between biofuels and combustion appliances (Table 4). The $\Sigma_{26}$ PAH EFs for 


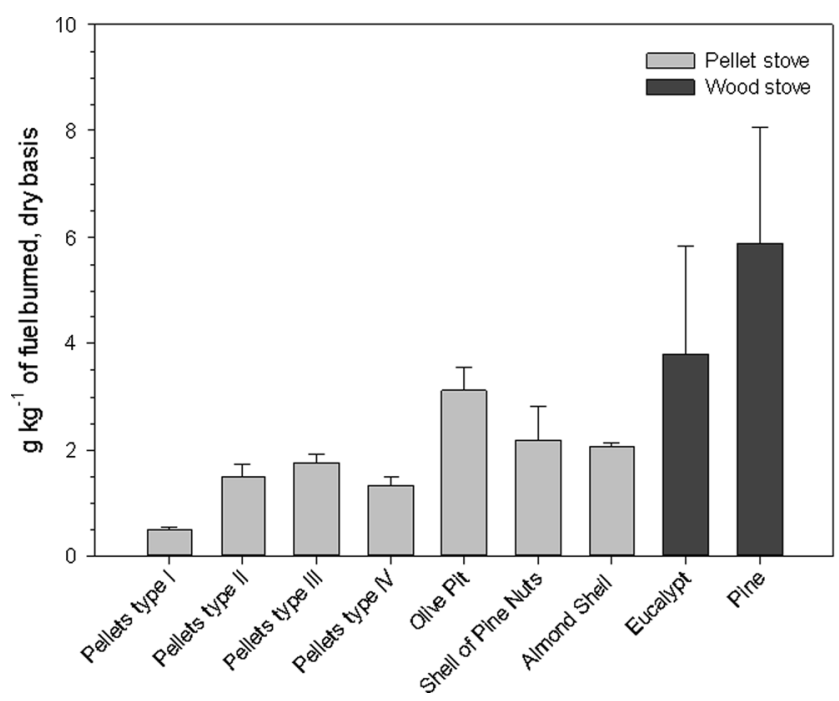

Fig. $1 \mathrm{PM}_{10}$ emission factors $(\mathrm{db})$ for the combustion of the distinct biofuels in the two combustion appliances

the pellet stove ranged from 46.3 (olive pit) to 513 (shell of pine nuts) $\mu \mathrm{g} \mathrm{kg}^{-1}$ of fuel burned, db. The $\Sigma_{26}$ PAH represented from 0.083 (pellets type III) to 40 (pellets type I) $\mu \mathrm{g} \mathrm{mg}^{-1}$ of the $\mathrm{PM}_{10}$ emitted. RET was the PAH with the highest EF for almost all the fuels. RET has been pointed out as a marker of conifer wood combustion since it is a pyrolysis product of resin acids (Pettersson et al. 2011; Ramdahl 1983; Shen et al. 2012c). Taking this into account, it is not surprising that shell of pine nuts present the highest RET EF $\left(250 \mathrm{\mu g} \mathrm{kg}^{-1}\right.$ of fuel burned, $\mathrm{db}$ ). The second highest $\mathrm{EF}$ was obtained for one type of pellets, with EN-Plus certification, made almost entirely of pine wood (137 $\mu \mathrm{g}$ RET kg-1 of fuel burned, $\mathrm{db})$. Shen et al. (2012c) reported RET EFs from 11 crop residues, 27 firewood and 5 coals using traditional rural Chinese stoves. The study reported that the crop RET EFs were not significantly lower than those for softwood. The EFs from coal combustion were the highest. Thus, the authors argued that RET is not a unique marker for softwood combustion and attention must be paid in PAH source apportionment (Shen et al. 2012c). Regardless of biofuel, other representative PAHs in $\mathrm{PM}_{10}$ emissions were PYR, PHE, BaA, CHR+TRY, THNAP, IcdP and BghiP. Boman et al. (2011) tested different pellet stoves and pellets and found that PAH emissions were generally dominated by PHE, FLT and PYR. Although THNAP, also known as tetralin, has previously been detected in urban aerosols (Bandowe et al. 2014), as far as we know, this is the first time that its presence is documented in particles from residential biomass combustion. In previous biomass burning studies, FLO has only been reported in the gas phase (Schauer et al. 2001). However, we have detected this compound in particles emitted by the pellet stove during the combustion of almost all fuels. The different sampling techniques and analytical methodologies can be the reason for the dissimilarities reported in the literature.
The experiments performed in the wood stove generated $\Sigma_{26}$ PAH EFs ranging from 329 to 1,972 and from 8,651 to 24, $302 \mu \mathrm{g} \mathrm{kg}^{-1}$ of fuel burned (db) for the combustion of eucalypt and pine, respectively. The parent and alkyl-PAH mass fraction in $\mathrm{PM}_{10}$ ranged from 0.28 to 0.40 and from 0.56 to $3.0 \mu \mathrm{g} \mathrm{mg}^{-1}$ for eucalypt and pine, respectively. The combustion of conifer logs are characterised by higher burning rates, which result in very hot flames and short, local drop of oxygen concentration, resulting in high emissions of PAHs. The most dominant PAHs from the combustion of eucalypt were PYR, $\mathrm{BaA}$ and CHR+TRY. For pine combustion, RET was the dominant compound, followed by PYR. BaA and FLT also presented high EFs for pine combustion. The highest PAH emissions were registered for both fuels during the devolatilisation phase. Leskinen et al. (2014) tested three different combustion conditions (efficient, intermediate and smouldering) and found that the total analysed PAH emission from the smouldering condition was over 1000 times higher than that from the efficient combustion. Several authors have reported larger variations between PAH emissions than between particulate emissions from different combustion conditions (Johansson et al. 2004; Orasche et al. 2012; Leskinen et al. 2014).

Pettersson et al. (2011) observed that at temperatures below $800{ }^{\circ} \mathrm{C}$, PHE, RET and FLT were the three dominant PAHs in the emissions from a residential wood stove. The combustion appliance is of high importance with regard to PAH emissions. Tissari et al. (2007) tested seven different burning appliances and found that the emission of all PAHs from a sauna stove were considerably higher than those from other burning appliances. The authors reported a total PAH EF of $164 \mathrm{mg} \mathrm{kg}^{-1}$ for the sauna stove, while a mean EF of $21 \mathrm{mg} \mathrm{kg}^{-1}$ was presented for other combustion devices.

From a carcinogenic point of view, $\mathrm{BaP}$ is the most important PAH (Hedberg et al. 2002). Sampling of urban particulate matter in Berlin showed that about two-thirds of the total PAH concentration were associated with particles smaller than $1.2 \mu \mathrm{m}$. The same study reported that $30 \%$ of the overall carcinogenicity of the samples, determined by a dose addition model, was due to BaP (Burkart et al. 2013). In the present study, $\mathrm{BaP}$ emissions varied from undetectable levels in samples from olive pit and some types of pellets to $17 \mu \mathrm{g} \mathrm{kg}^{-1}$ in the smoke from shell of pine nuts. However, the $\mathrm{PM}_{10}$ mass fraction reached $912 \mathrm{ng} \mathrm{mg}^{-1}$ for the EN-Plus labelled type of pellets, whilst a value of $19.4 \mathrm{ng} \mathrm{mg}^{-1}$ was obtained for shell of pine nuts. The mass fraction of $\mathrm{BaP}$ in $\mathrm{PM}_{10}$ in emissions from the wood stove ranged from 22.7 to 23.4 and from 23.6 to $47.9 \mathrm{ng} \mathrm{mg}^{-1}$ for eucalypt and pine combustion, respectively. BaP formation during the combustion process depends strongly on temperature and oxygen concentration in the burning chamber. It is necessary to draw attention to the fact that emission data from literature are not perfectly comparable. The BaP emission phase and particle size fraction may differ 


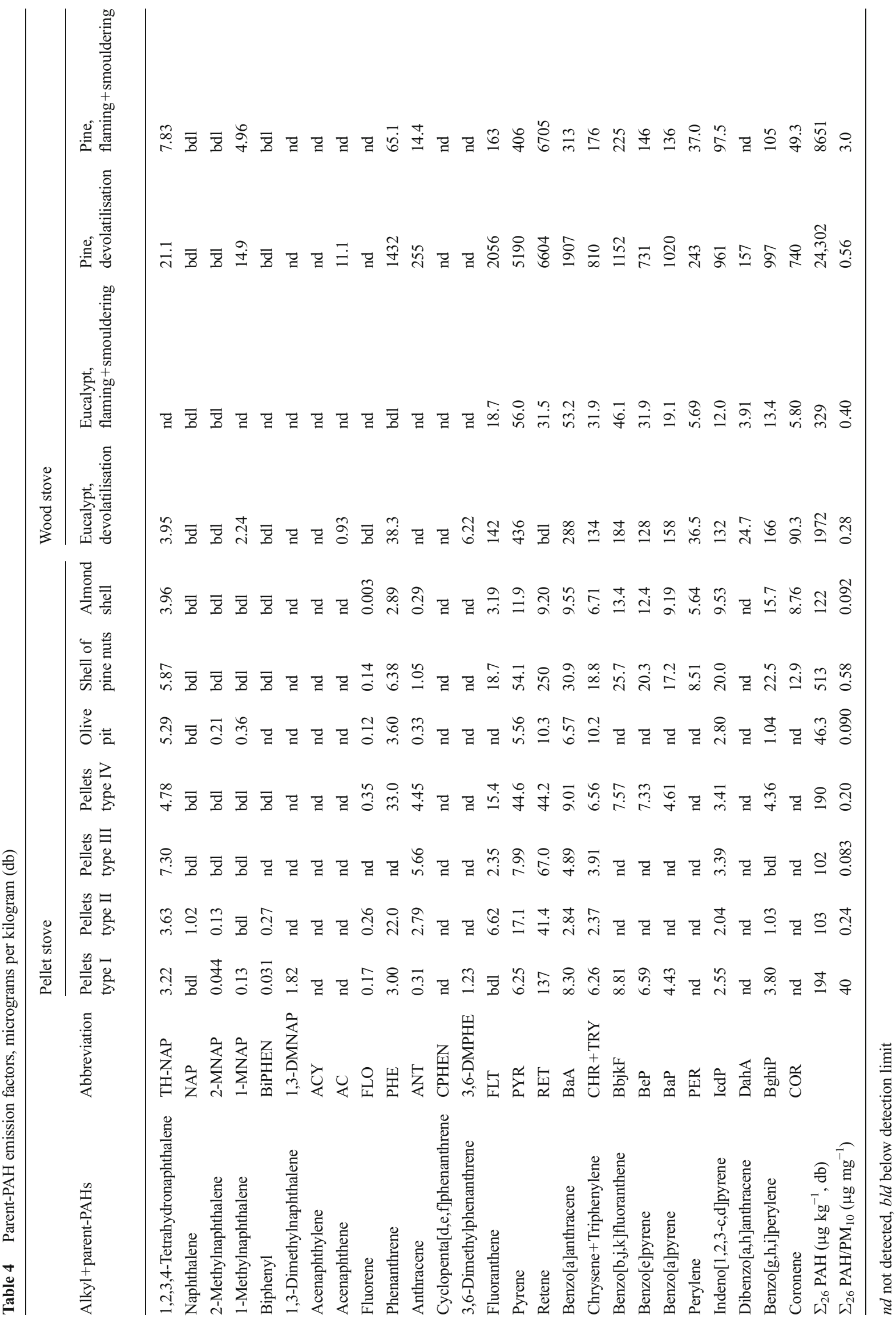


between studies (Table 3). However, it has been reported that $\mathrm{BaP}$ is mainly present in the particulate phase (Oanh et al. 1999) and also that the particle-bound PAH emissions from wood combustion are mainly associated with fine particulate matter (more than $85 \%$ ) with size less than $2.1 \mu \mathrm{m}$ (Shen et al. 2013b). In the literature, the lowest BaP levels have been reported for pellet stoves and the highest for sauna stoves (Table 5). In the present study, BaP represented, on average, $236 \mathrm{mg} \mathrm{g}^{-1}$ of $\mathrm{PM}_{10}$ emitted from the pellet stove. This appliance registered significantly lower BaP EFs that the traditional wood stove. The lowest emitting wood species generated more than 4 times higher $\mathrm{BaP}$ concentrations than pellets. The combustion of conifer logs are characterised by higher emissions of BaP.

Parent PAH isomer ratios are often used as source apportionment tools (Alves 2008). The IcdP/(BghiP+IcdP), FLT/ (FLT+PYR) and BaP/BghiP diagnostic ratios are listed and compared with those of other sources in Table 6. Although it is possible to clearly distinguish the FLT/(FLT+PYR) ratio of biomass combustion from those of petrogenic emissions, the separation between sources using other PAH ratios is tricky, because overlapping of values may occur. The FLT/(FLT+ PYR) ratio was $0.25 \pm 0.03$ and $0.27 \pm 0.02$ for the pellet stove and wood stove, respectively. Higher ratios have been obtained for coal combustion (Chen et al. 2004), cereal straw (Hays et al. 2005) and grasses (Oros et al. 2006). The ratios were also lower than those documented for fossil fuel combustion (de la Torre-Roche et al. 2009). The ratio reported for biomass burning by Kalaitzoglou et al. (2004) is in good agreement with those of the present study. Gonçalves et al. (2011) obtained $\mathrm{IcdP} /(\mathrm{BghiP}+\mathrm{IcdP})$ ratios of $0.59 \pm 0.05$ and $0.61 \pm 0.11$ for a wood stove and a fireplace, respectively. In the present study, lower values of $0.51 \pm 0.15$ and $0.47 \pm 0.020$ were determined for the pellet stove and wood stove, respectively. Kalaitzoglou

Table 5 Comparison of benzo[a]pyrene emission factors from this study and literature values

\begin{tabular}{|c|c|c|c|c|c|}
\hline Appliance & Fuel & $\begin{array}{l}\text { PM } \\
\text { fraction }\end{array}$ & $\mathrm{BaP}$ emission phase & $\begin{array}{l}\mathrm{BaP} \mathrm{EF} \\
\left(\mathrm{mg} \mathrm{kg}^{-1}\right)\end{array}$ & Reference \\
\hline \multirow[t]{2}{*}{ Fireplace } & $\begin{array}{l}\text { Softwood (pine) } \\
\text { Hardwoods }\end{array}$ & \multirow[t]{2}{*}{$\mathrm{PM}_{2.5}$} & \multirow[t]{2}{*}{ Particle phase } & $\begin{array}{l}0.218 \\
0.063-0.785\end{array}$ & \multirow[t]{2}{*}{ Gonçalves et al. (2012) } \\
\hline & Briquettes & & & 0.025 & \\
\hline \multirow[t]{2}{*}{ Fireplace } & $\begin{array}{l}\text { Oak wood } \\
\text { Eucalypt wood }\end{array}$ & \multirow[t]{2}{*}{$\mathrm{PM}_{1.8}$} & \multirow[t]{2}{*}{ Particle and gas phase } & $\begin{array}{l}0.25 \\
0.3\end{array}$ & \multirow[t]{2}{*}{ Schauer et al. (2001) } \\
\hline & Pine wood & & & 0.71 & \\
\hline Fireplace & $\begin{array}{l}\text { Oak wood } \\
\text { Pine wood }\end{array}$ & $\mathrm{PM}_{10}$ & Particle phase & $\begin{array}{l}0.23 \\
0.62\end{array}$ & Rogge et al. (1998) \\
\hline Open fireplace & $\begin{array}{l}\text { Beech, spruce, hombeam, } \\
\text { false acacia and oak }\end{array}$ & $\mathrm{PM}_{\text {tot }}$ & Particle and gas phase & $0.182-0.587$ & Ozgen et al. (2014) \\
\hline Closed fireplace & Hardwood and softwood & \multirow[b]{2}{*}{$\mathrm{PM}_{2.5}$} & \multirow[b]{2}{*}{ Particle phase } & $0.085-0.463$ & \multirow[b]{2}{*}{ Gonçalves et al. (2012) } \\
\hline Wood stove & $\begin{array}{l}\text { Softwood (pine) } \\
\text { Hardwoods } \\
\text { Briquettes }\end{array}$ & & & $\begin{array}{l}0.096 \\
0.078-0.482 \\
0.072\end{array}$ & \\
\hline Wood stove & Birch wood & $\mathrm{PM}_{2.5}$ & Particle and gas phase & $0.2-16.0$ & Hedberg et al. (2002) \\
\hline Fireplace and wood stove & Hardwood and softwood & $\mathrm{PM}_{2.5}$ & Particle phase & $0.15-0.34$ & McDonald et al. (2000) \\
\hline $\begin{array}{l}\text { Wood stove } \\
\text { Advanced wood stove }\end{array}$ & $\begin{array}{l}\text { Beech, Hombeam, False Acacia, Oak } \\
\text { Beech and spruce }\end{array}$ & $\mathrm{PM}_{\text {tot }}$ & Particle and gas phase & $\begin{array}{l}0.066-10.3 \\
0.671-8.50\end{array}$ & Ozgen et al. (2014) \\
\hline $\begin{array}{l}\text { Sauna stove } \\
\text { Conventional masonry heater }\end{array}$ & $\begin{array}{l}\text { Alder and aspen wood } \\
\text { Birch wood }\end{array}$ & \multirow[t]{2}{*}{$\mathrm{PM}_{1}$} & \multirow[t]{2}{*}{ Particle and gas phase } & $\begin{array}{l}14.88 \\
0.39\end{array}$ & \multirow[t]{2}{*}{ Tissari et al. (2007) } \\
\hline Conventional masonry heater & Spruce wood & & & 0.15 & \\
\hline Chinese cooking stove & 27 fuels & $\mathrm{PM}_{\mathrm{tot}}$ & Particle and gas phase & $0.019-0.13$ & Shen et al. (2012b) \\
\hline Pellets stove & $\begin{array}{l}\text { High quality pellet } \\
\text { Low quality pellet }\end{array}$ & \multirow[t]{2}{*}{$\mathrm{PM}_{\text {tot }}$} & \multirow[t]{2}{*}{ Particle and gas phase } & $\begin{array}{l}0.035 \\
0.021\end{array}$ & \multirow[t]{2}{*}{ Ozgen et al. (2014) } \\
\hline Pellets boiler & $\begin{array}{l}\text { High quality pellet } \\
\text { Low quality pellet }\end{array}$ & & & $\begin{array}{l}0.0015 \\
0.00076\end{array}$ & \\
\hline Pellet stove & $\begin{array}{l}\text { Wood pellets } \\
\text { Agro fuels }\end{array}$ & \multirow[t]{3}{*}{$\mathrm{PM}_{10}$} & \multirow[t]{3}{*}{ Particle phase } & $\begin{array}{l}0.0044-0.0046 \\
0.0092-0.017\end{array}$ & \multirow[t]{3}{*}{ This study } \\
\hline Wood stove & Pine wood & & & $0.136-1.020$ & \\
\hline & Eucalypt wood & & & $0.019-0.158$ & \\
\hline
\end{tabular}


Table 6 PAH diagnostic ratios

\begin{tabular}{|c|c|c|c|c|}
\hline & $\mathrm{FLT} /(\mathrm{FLT}+\mathrm{PYR})$ & IcdP/(BghiP + IcdP $)$ & $\mathrm{BaP} / \mathrm{BghiP}$ & References \\
\hline Pellets type I & - & 0.40 & 1.17 & \multirow[t]{7}{*}{ This study (pellet stove) } \\
\hline Pellets type II & 0.28 & 0.66 & - & \\
\hline Pellets type III & 0.23 & - & - & \\
\hline Pellets type IV & 0.26 & 0.44 & 1.06 & \\
\hline Olive pit & - & 0.73 & - & \\
\hline Shell of pine nuts & 0.26 & 0.47 & 0.77 & \\
\hline Almond shell & 0.21 & 0.38 & 0.59 & \\
\hline Eucalypt, devolatilisation & 0.25 & 0.44 & 0.95 & \multirow[t]{4}{*}{ This study (wood stove) } \\
\hline Eucalypt, flaming + smouldering & 0.25 & 0.47 & 1.42 & \\
\hline Pine, devolatilisation & 0.28 & 0.49 & 1.02 & \\
\hline Pine, flaming + smouldering & 0.29 & 0.48 & 1.29 & \\
\hline $\begin{array}{l}\text { Petrogenic } \\
\text { Petroleum combustion }\end{array}$ & & $\begin{array}{l}<0.2 \\
0.2-0.5\end{array}$ & & \multirow[t]{2}{*}{ Yunker et al. (2002) } \\
\hline Grass, wood and coal combustion & & $>0.5$ & & \\
\hline Coal & & 0.43 & & Chen et al. (2004) \\
\hline Cereal straw & & $0.52-1.0$ & & Hays et al. (2005) \\
\hline $\begin{array}{l}\text { Non-traffic emissions } \\
\text { Traffic emissions }\end{array}$ & & & $\begin{array}{l}<0.6 \\
>0.6\end{array}$ & Katsoyiannis et al. (2007) \\
\hline Biomass burning & 0.26 & 0.44 & & Kalaitzoglou et al. (2004) \\
\hline Petrogenic & $<0.4$ & & & \multirow[t]{2}{*}{ De La Torre-Roche et al. (2009) } \\
\hline Fossil ruel combustion & $\begin{array}{l}0.4-0.5 \\
>0.5\end{array}$ & & & \\
\hline Coal & 0.48 & & & Chen et al. (2004) \\
\hline Cereal straw & $0.50-0.53$ & & & Hays et al. (2005) \\
\hline Grasses & $0.53-0.63$ & & & Oros et al. (2006) \\
\hline
\end{tabular}

et al. (2004) reported a ratio of 0.44 for biomass burning, which is close to the values here obtained. However, the values obtained for biomass burning in the present study overlap those described by Yunker et al. (2002) for petroleum combustion. The BaP/BghiP ratio was $0.89 \pm 0.27$ and $1.17 \pm$ 0.22 for the pellet stove and wood stove, respectively. The $\mathrm{BaP} / \mathrm{BghiP}$ ratio superimposes those of vehicle exhaust, making questionable its use as source assignment tool.

\section{OPAHs}

Besides PAHs, OPAHs play a major role in the toxic potential of PM from wood combustion (Orasche et al. 2012). For the pellet stove, the $\Sigma_{15}$ OPAH EFs ranged from 4.00 (pellets type III) to 240 (pellets type I) $\mu \mathrm{g} \mathrm{kg}-1$ of fuel burned, $\mathrm{db}$. The 15 OPAHs represented from 0.003 (pellets type III) to 5.3 (pellets type I) $\mu \mathrm{g} \mathrm{mg}^{-1}$ of the $\mathrm{PM}_{10}$ emitted (Table 7 ). Among the OPAHs measured, 9-FLU was present in all samples. The number of different OPAHs was greater in samples from the combustion of EN-Plus labelled pellets (type I). Shen et al. (2012a) determined the OPAH EFs from two types of pellets (pine wood pellets and corn straw pellets) in a modern pellet burner. The effect of secondary air supply on emissions was also tested. The dominant OPAHs were 9-FLU and 9,10ANQ. The lowest EFs were obtained for pine pellets. Lower OPAH EFs were observed for the combustion without secondary air supply (77.7-189 $\left.\mathrm{g} \mathrm{kg} \mathrm{k}^{-1}\right)$ than when secondary air was drawn into the firebox $\left(348-396 \mu \mathrm{g} \mathrm{kg}^{-1}\right)$. Iinuma et al. (2007) carried out a chemical characterisation of particle emissions from the combustion of European conifer species, savannah grass, African hardwood, and German and Indonesian peat. OPAH EFs ranged from 80 to $1,000 \mu \mathrm{g} \mathrm{kg}^{-1}$. Differences in the combustion technology and fuels may justify the differences between the EFs found in the literature compared with those obtained in the present study.

The wood stove generated OPAH EFs ranging from 121 to 1,456 and from 1,645 to $10,141 \mu \mathrm{g} \mathrm{kg}^{-1}$ of fuel burned (db), for the combustion of eucalypt and pine, respectively. The OPAH mass fraction in $\mathrm{PM}_{10}$ ranged from 0.15 to 0.21 and from 0.24 to $0.58 \mu \mathrm{g} \mathrm{mg}^{-1}$ for eucalypt and pine, respectively. The OPAHs emissions were higher during the initial stage of combustion, which is characterised by fast devolatilisation of the fuel. Albeit the $\mathrm{O}_{2}$ availability, the released compounds are not oxidised as a result of low temperatures and poor mixing conditions between the combustion air and the flue gas, leading to high emissions of products from incomplete 


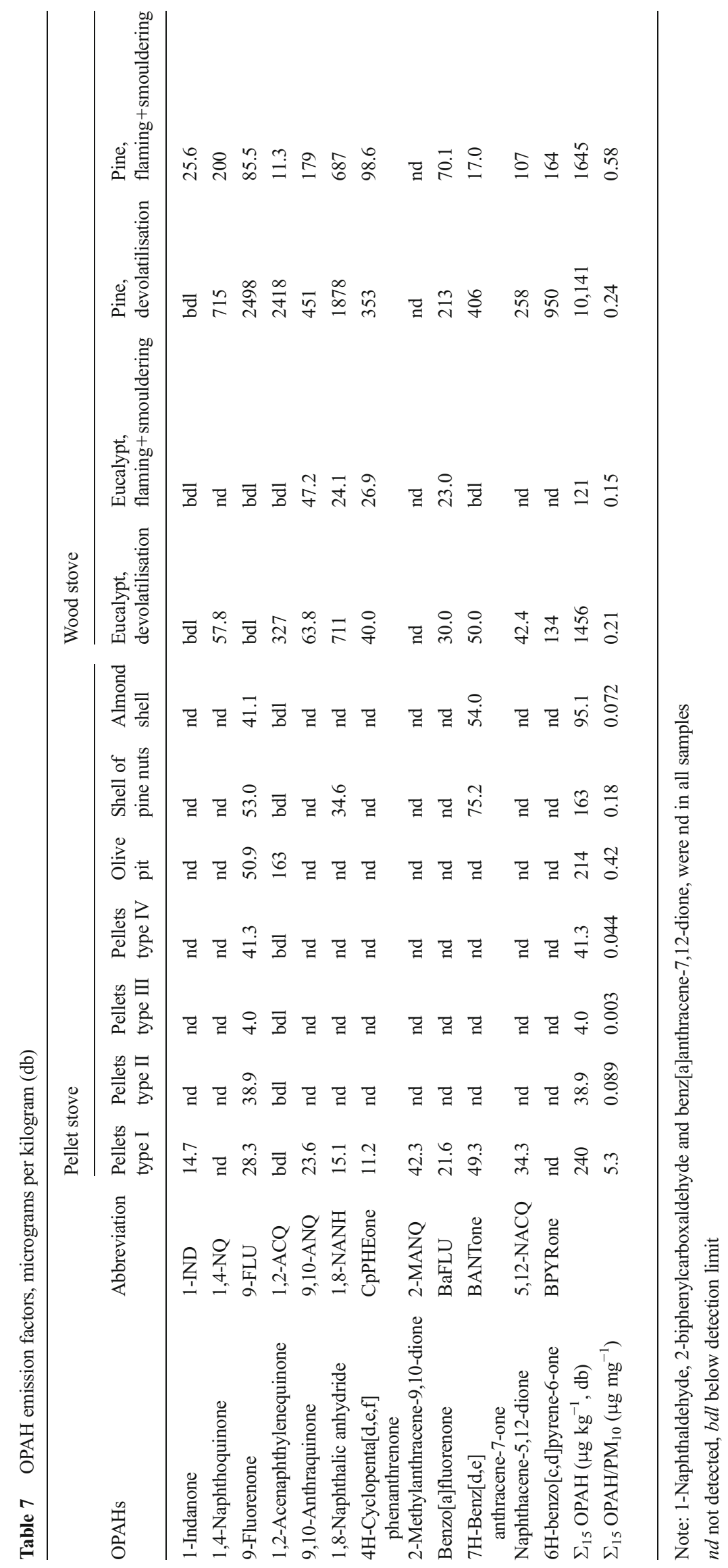


combustion (Vicente et al. 2015a). During the devolatilisation stage of eucalypt combustion, high amounts of 1,8-NANH and 1,2-ACQ were produced. Over the remaining combustion cycle, 9,10-ANQ and CpPHEone were the OPAHs with higher EFs. For pine combustion, samples from the devolatilisation phase were dominated by 9 -FLU and 1,2ACQ. The flaming and smouldering combustion phases generated higher 1,8-NANH and 1,4-NQ EFs.

Shen et al. (2013a) conducted combustion experiments in a typical brick cooking stove in order to investigate the effect of operation conditions on four OPAH emissions. The lowest EF $\left(0.52 \pm 0.43 \mathrm{mg} \mathrm{kg}^{-1}\right)$ was recorded for normal burning conditions. The EF increased to $7.8 \pm 3.6 \mathrm{mg} \mathrm{kg}^{-1}$ during the combustion with restricted air. Among the OPAHs detected in their study, 9-FLU was the most abundant. Shen et al. (2012b) tested 27 different fuels in a typical brick stove used in Northern China. Once again, 9-FLU was the dominant OPAH in particulate matter samples.

\section{AZAs}

The $\Sigma_{4}$ AZA EFs for the pellet stove ranged from 0.41 (pellets type IV) to 18.0 (almond shell) $\mu \mathrm{g} \mathrm{kg}^{-1}$ of fuel burned, $\mathrm{db}$. The $\Sigma_{4}$ AZAs represented between a negligible mass fraction (pellets type IV) and 0.014 (almond shell) $\mu \mathrm{g} \mathrm{mg}^{-1}$ of the $\mathrm{PM}_{10}$ emitted.

BQI was the compound more frequently encountered in $\mathrm{PM}_{10}$ samples from the combustion in the pellet stove. CBZ was only present in $\mathrm{PM}_{10}$ from almond shell, representing the AZA emitted at highest amount by the automatic feeding appliance. $\mathrm{CBZ}$ was also the single compound in $\mathrm{PM}_{10}$ from the combustion of pine. This AZA can be associated with the devolatilisation phase, since it was absent from samples obtained during the subsequent flaming and smouldering combustion stages, either for pine or eucalypt. Besides CBZ, throughout the entire combustion cycle, QUI was also emitted when eucalypt was burned. It was found that AZA emissions from the traditional wood stove may be up to 1,420 times higher than those from the automatic pellet stove (Table 8).

\section{NPAHs}

For the pellet stove, the $\Sigma_{15}$ NPAH EFs ranged from 26.6 (pellets type II) to 158 (shell of pine nuts) $\mathrm{\mu g} \mathrm{kg}^{-1}$ of fuel burned, db (Table 9). Excluding samples from the combustion of pellets type I and shell of pine nuts, in which 6-NitroCHRY was also quantified, 5-NitroACEN was the only NPAH detected in the remaining samples. NPAHs represented between 0.025 (pellets type III) and 6.5 (pellets type I) $\mu \mathrm{g} \mathrm{mg}^{-1}$ of the $\mathrm{PM}_{10}$ mass.

The EFs for the combustion of eucalypt and pine in the wood stove varied from 204 to 891 and from 2,163 to 4 , $248 \mu \mathrm{g} \mathrm{kg}^{-1}$ of fuel burned (db), respectively. Shen et al. 
(2013a) observed that the emissions of PAHs, OPAHs and NPAHs were 2-4 times higher during fast burning. These conditions can easily be achieved when burning softwood (Vicente et al. 2015a) leading to oxygen starvation and, consequently, to higher emissions. NPAHs accounted for 0.13 to 0.25 and from 0.098 to $0.76 \mu \mathrm{g} \mathrm{mg}^{-1}$ of the $\mathrm{PM}_{10}$ mass emitted during the combustion of eucalypt and pine, respectively.

During the devolatilisation stage of eucalypt, the dominant NPAHs were 5-NitroACEN and 2,7-DNitroFLUO. 5NitroACEN, followed by 6-NitroCHRY, were the prevalent NPAHs during the flaming and smouldering combustion phases. Higher amounts of 5-NitroACEN over the entire combustion cycle were generated when the wood stove was fed with pine. When devolatilisation of this softwood takes places, 1-NitroPYR and 6-NitroCHRY are also detected, while throughout the following stages (flaming and smouldering) the formation of 2,7-DNitroFLUO and 6-NitroCHRY occurs. Shen et al. (2013a) observed that 1-NitroNAPH and 2-NitroNAPH were the dominant NPAHs in the emissions of a cooking stove. Shen et al. (2012b) also pointed out NitroNAPH as a dominant NPAH in samples from the burning of 27 different fuels in a typical Chinese stove.

In the present study, parent-PAHs were around 2-6-fold higher than NPAHs. Previous studies reported that NPAHs from residential wood combustion were about 2-3 orders of magnitude lower than parent PAHs (Shen et al. 2012b, 2013a). The PAH derivatives are more likely to be found in the particulate-phase in comparison with the corresponding parent-PAHs due to the lower vapour pressure (Shen et al. 2012b). Since our study only reports particle-bound PAHs and derivatives the difference may derive from the fact that many literature values also include gas-phase measurements, increasing the proportion of parent-PAH emissions in comparison with NPAHs.

\section{Conclusions}

Most emission studies have been focused on the occurrence of non-substituted PAHs. PAH derivatives, namely OPAHs, AZAs and NPAHs, have been significantly less addressed, while they seem more toxic than their parent compounds. This work provides original information on parent PAHs, OPAHs, AZAs and NPAH emissions from residential combustion of biofuels commonly used in households. Some of these are emergent biofuels, but their consumption has been promoted, presenting a marked tendency to rise.

PAC emissions from the manually fed traditional stove may be up to 145 times higher than those of the automatic pellet stove. The devolatilisation phase of softwood in the traditional appliance is particularly worrying, because $\mathrm{BaP}$ emissions can be more than 1,000 times higher than the values 
registered for any other combustion stages, appliance or biofuels.

RET was the dominant PAH in softwood smoke, whilst it was absent or detected at trace levels in particles emitted from the combustion of eucalypt. In the pellet stove experiments, shell of pine nuts presented the highest RET emission values, followed by the emissions from the EN-Plus certified pellets, which were made almost entirely of pine wood. Thus, RET can be pointed out as a good candidate for tracing coniferous biomass burning. Among OPAHs, 9-FLU was present in all samples from the pellet stove, whereas $1,8-\mathrm{NANH}$ was the most representative ubiquitous compound in emissions from the traditional wood stove. AZAs were absent in the majority of samples. Only CBZ in samples from the combustion of almond shell and the devolatilisation phase of both woods and QUI in emissions from eucalypt deserve recognition. Concerning NPAH emissions, 5-NitroACEN was an everpresent compound, regardless of biofuel or combustion device, while 6-NitroCHRY was specifically emitted by the wood stove.

The results showed that PAC emissions are dependent on combustion technology and biofuel types. To better understand the influence of combustion parameters on emissions, future studies focusing this research topic should be performed. It is also recommended to obtain speciated emissions from the start-up combustion phase, since it has been demonstrated that ignition may have much higher emissions of byproducts that harm human health. The information provided by this study can be very useful to estimate carcinogenic risks associated with biomass burning emissions, as well as to improve emission inventories and source apportionment methodologies.

Acknowledgements This work was financially supported by AIRUSETesting and development of air quality mitigation measures in Southern Europe, LIFE 11 ENV/ES/000584. Ana Vicente acknowledges the Postdoc grant SFRH/BPD/88988/2012 from the Portuguese Science Foundation (FCT) and the financing programme POPH/FSE.

\section{References}

Albinet A, Leoz-Garziandia E, Budzinski H, Villenave E, Jaffrezo J-L (2008) Nitrated and oxygenated derivatives of polycyclic aromatic hydrocarbons in the ambient air of two French alpine valleys part 2: particle size distribution. Atmos Environ 42(1):55-64

Alves CA (2008) Characterisation of solvent extractable organic constituents in atmospheric particulate matter: an overview. Ann Braz Acad Sci 80(1):21-82

Alves C, Gonçalves C, Fernandes AP, Tarelho L, Pio C (2011) Fireplace and woodstove fine particle emissions from combustion of western Mediterranean wood types. Atmos Res 101(3):692-700

Bandowe BAM, Wilcke W (2010) Analysis of polycyclic aromatic hydrocarbons and their oxygen-containing derivatives and metabolites in soils. J Environ Qual 39(4):1349-1358
Bandowe BAM, Meusel H, Huang R-J, Ho K, Cao J, Hoffmann T, Wilcke W (2014) $\mathrm{PM}_{2.5}$-bound oxygenated PAHs, nitro-PAHs and parent-PAHs from the atmosphere of a Chinese megacity: seasonal variation, sources and cancer risk assessment. Sci Total Environ 473-474:77-87

Belis CA, Cancelinha J, Duane M, Forcina V, Pedroni V, Passarella R, Tanet G, Douglas K, Piazzalunga A, Bolzacchini E, Sangiorgi G, Perrone M-G, Ferrero L, Fermo P, Larsen BR (2011) Sources for PM air pollution in the Po Plain, Italy: I. Critical comparison of methods for estimating biomass burning contributions to benzo(a)pyrene. Atmos Environ 45(39):7266-7275

Bernardoni V, Vecchi R, Valli G, Piazzalunga A, Fermo P (2011) $\mathrm{PM}_{10}$ source apportionment in Milan (Italy) using time-resolved data. Sci Total Environ 409(22):4788-4795

Bleeker EAJ, Van der Geest HG, Klamer HJC, De Voogt P, Wind E, Kraak MHS (1999) Toxic and genotoxic effects of azaarenes: isomers and metabolites. Polycycl Aromat Comp 13:191-203

Bleeker EAJ, Wiegman S, de Voogt P, Kraak M, Leslie HA, de Haas E, Admiraal W (2002) Toxicity of azaarenes. Rev Environ Contam Toxicol 173:39-83

Boman C, Nordin A, Westerholm R, Pettersson E (2005) Evaluation of a constant volume sampling setup for residential biomass fired appliances - influence of dilution conditions on particulate and PAH emissions. Biomass Bioenerg 29:258-268

Boman C, Pettersson E, Westerholm R, Boström D, Nordin A (2011) Stove performance and emission characteristics in residential wood $\log$ and pellet combustion, part 1: pellet stoves. Energ Fuel 25(1): 307-314

Boström C-E, Gerde P, Hanberg A, Jernström B, Johansson C, Kyrklund T, Rannug A, Törnqvist M, Victorin K, Westerholm R (2002) Cancer risk assessment, indicators, and guidelines for polycyclic aromatic hydrocarbons in the ambient air. Environ Health Perspect 110(s3):451-489

Bressi M, Sciare J, Ghersi V, Mihalopoulos N, Petit J-E, Nicolas JB, Moukhtar S, Rosso A, Féron A, Bonnaire N, Poulakis E, Theodosi C (2014) Sources and geographical origins of fine aerosols in Paris (France). Atmos Chem Phys 14(16):8813-8839

Burkart K, Nehls I, Win T, Endlicher W (2013) The carcinogenic risk and variability of particulate-bound polycyclic aromatic hydrocarbons with consideration of meteorological conditions. Air Qual Atmos Health 6:27-38

Calvo AI, Tarelho LAC, Alves CA, Duarte M, Nunes T (2014) Characterization of operating conditions of two residential wood combustion appliances. Fuel Process Technol 126:222-232

Chen Y, Bi X, Mai B, Sheng G, Fu J (2004) Emission characterization of particulate/gaseous phases and size association for polycyclic aromatic hydrocarbons from residential coal combustion. Fuel 83(7-8): 781-790

Chuesaard T, Chetiyanukornkul T, Kameda T, Hayakawa K, Toriba A (2014) Influence of biomass burning on the levels of atmospheric polycyclic aromatic hydrocarbons and their nitro derivatives in Chiang Mai, Thailand. Aerosol Air Qual Res 14:1247-1257

Claxton LD, Matthews PP, Warren SH (2004) The genotoxicity of ambient outdoor air, a review: Salmonella mutagenicity. Mutat Res 567: 347-399

De La Torre-Roche RJ, Lee W-Y, Campos-Díaz SI (2009) Soil-borne polycyclic aromatic hydrocarbons in El Paso, Texas: analysis of a potential problem in the United States/Mexico border region. J Hazard Mater 163(2-3):946-958

Durant JL, Busby WF, Lafleur AL, Penman BW, Crespi CL (1996) Human cell mutagenicity of oxygenated, nitrated and unsubstituted polycyclic aromatic hydrocarbons associated with urban aerosols. Mutat Res Toxicol 371(3-4):123-157

Fernandes AP, Alves CA, Gonçalves C, Tarelho L, Pio C, Schimdl C, Bauer H (2011) Emission factors from residential combustion 
appliances burning Portuguese biomass fuels. J Environ Monitor 13: 3196-3206

Garcia-Maraver A, Zamorano M, Fernandes U, Rabaçal M, Costa M (2014) Relationship between fuel quality and gaseous and particulate matter emissions in a domestic pellet-fired boiler. Fuel 119:141152

Gonçalves C, Alves C, Evtyugina M, Mirante F, Pio C, Caseiro A, Schmidl C, Bauer H, Carvalho F (2010) Characterisation of $\mathrm{PM}_{10}$ emissions from woodstove combustion of common woods grown in Portugal. Atmos Environ 44(35):4474-4480

Gonçalves C, Alves C, Fernandes AP, Monteiro C, Tarelho L, Evtyugina $\mathrm{M}$, Pio C (2011) Organic compounds in $\mathrm{PM}_{2.5}$ emitted from fireplace and woodstove combustion of typical portuguese wood species. Atmos Environ 45(27):4533-4545

Gonçalves C, Alves C, Pio C (2012) Inventory of fine particulate organic compound emissions from residential wood combustion in Portugal. Atmos Environ 50:297-306

Hays MD, Fine PM, Geron CD, Kleeman MJ, Brian KG (2005) Open burning of agricultural biomass: physical and chemical properties of particle-phase emissions. Atmos Environ 39(36):6747-6764

Hedberg E, Kristensson A, Ohlsson M, Johansson C, Johansson P-A, Swietlicki E, Vesely V, Wideqvist U, Westerholm R (2002) Chemical and physical characterization of emissions from birch wood combustion in a wood stove. Atmos Environ 36:4823-4837

Huang W, Zhu T, Pan X, Hu M, Lu S-E, Lin Y, Wang T, Zhang Y, Tang X (2012) Air pollution and autonomic and vascular dysfunction in patients with cardiovascular disease: interactions of systemic inflammation, overweight, and gender. Am J Epidemiol 176(2):117-126

Hytonen K, Yli-Pirila P, Tissari J, Grohn A, Riipinen I, Lehtinen KEJ, Jokiniemi J (2009) Gas-particle distribution of PAHs in wood combustion emission determined with annular denuders, filter, and polyurethane foam adsorbent. Aerosol Sci Technol 43:442-454

ICNF (2013) IFN6-Áreas dos usos do solo e das espécies florestais de Portugal continental. Resultados preliminares. Instituto da Conservação da Natureza e das Florestas, Lisboa, p 34

Iinuma Y, Brüggemann E, Gnauk T, Müller K, Andreae MO, Helas G, Parmar R, Herrmann H (2007) Source characterization of biomass burning particles: the combustion of selected European conifers, African hardwood, savanna grass, and German and Indonesian peat. J Geophys Res 112, D08209

Johansson LS, Leckner B, Gustavsson L, Cooper D, Tullin C, Potter A (2004) Emission characteristics of modern and old-type residential boilers fired with wood logs and wood pellets. Atmos Environ 38(25):4183-4195

Kalaitzoglou M, Terzi E, Samara C (2004) Patterns and sources of particle-phase aliphatic and polycyclic aromatic hydrocarbons in urban and rural sites of western Greece. Atmos Environ 38(16): $2545-2560$

Katsoyiannis A, Terzi E, Cai Q-Y (2007) On the use of PAH molecular diagnostic ratios in sewage sludge for the understanding of the PAH sources. Is this use appropriate? Chemosphere 69(8):1337-1339

Lamberg H, Nuutinen K, Tissari J, Ruusunen J, Yli-Pirilä P, Sippula O, Tapanainen M, Jalava P, Makkonen U, Teinilä K, Saarnio K, Hillamo R, Hirvonen M-R, Jokiniemi J (2011) Physicochemical characterization of fine particles from small-scale wood combustion. Atmos Environ 45(40):7635-7643

Leskinen J, Tissari J, Uski O, Virén A, Torvela T, Kaivosoja T, Lamberg H, Nuutinen I, Kettunen T, Joutsensaari J, Jalava PI, Sippula O, Hirvonen M-R, Jokiniemi J (2014) Fine particle emissions in three different combustion conditions of a wood chip-fired applianceparticulate physico-chemical properties and induced cell death. Atmos Environ 86:129-139

Lippmann M (2012) Particulate matter (PM) air pollution and health: regulatory and policy implications. Air Qual Atmos Health 5:237241
Lu H, Zhu L, Zhu N (2009) Polycyclic aromatic hydrocarbon emission from straw burning and the influence of combustion parameters. Atmos Environ 43:978-983

McDonald JD, Zielinska B, Fujita EM, Sagebiel JC, Chow JC, Watson JG (2000) Fine particle and gaseous emission rates from residential wood combustion. Environ Sci Technol 34(11):2080-2091

Monteiro A, Miranda AI, Borrego C, Vautard R, Ferreira J, Perez AT (2007) Long-term assessment of particulate matter using CHIMERE model. Atmos Environ 41(36):7726-7738

Oanh NTK, Reutergårdh LB, Dung NT (1999) Emission of polycyclic aromatic hydrocarbons and particulate matter from domestic combustion of selected fuels. Environ Sci Technol 33:2703-2709

Oanh NTK, Nghiem LH, Phyu YL (2002) Emission of polycyclic aromatic hydrocarbons, toxicity, and mutagenicity from domestic cooking using sawdust briquettes, wood, and kerosene. Environ Sci Technol 36(5):833-839

Obaidullah M, Bram S, Verma VK, De Ruyck J (2012) A review on particle emissions from small scale biomass combustion. Int $\mathrm{J}$ Renew Energy Res 2(1):147-159

Orasche J, Seidel T, Hartmann H, Schnelle-kreis J, Chow JC, Ruppert H, Zimmermann R (2012) Comparison of emissions from wood combustion. Part 1: emission factors and characteristics from different small-scale residential heating appliances considering particulate matter and polycyclic aromatic hydrocarbon (PAH)-related toxicological potential. Energ Fuel 26:6695-6704

Oros DR, Abas MR, Omar NYMJ, Rahman NA, Simoneit BRT (2006) Identification and emission factors of molecular tracers in organic aerosols from biomass burning: part 3. Grasses. Appl Geochem 21(6):919-940

Ostro BD, Feng W-Y, Broadwin R, Malig BJ, Green RS, Lipsett MJ (2008) The impact of components of fine particulate matter on cardiovascular mortality in susceptible subpopulations. Occup Environ Med 65(11):750-756

Ozgen S, Caserini S, Galante S, Giugliano M, Angelino E, Marongiu A, Hugony F, Migliavacca G, Morreale C (2014) Emission factors from small scale appliances burning wood and pellets. Atmos Environ 94: 144-153

Pedersen DU, Durant JL, Penman BW, Crespi CL, Hemond HF, Lafleur AL, Cass GR (2004) Human-cell mutagens in respirable airborne particles in the northeastern United States. 1. Mutagenicity of fractionated samples. Environ Sci Technol 38(3):682-689

Pettersson E, Boman C, Westerholm R, Boström D, Nordin A (2011) Stove performance and emission characteristics in residential wood $\log$ and pellet combustion, part 2: wood stove. Energ Fuel 25(1): 315-323

Ramdahl T (1983) Retene e a molecular marker of wood combustion in ambient air. Nature 306:580-582

Reche C, Viana M, Amato F, Alastuey A, Moreno T, Hillamo R, Teinilä K, Saarnio K, Seco R, Peñuelas J, Mohr C, Prévôt ASH, Querol X (2012) Biomass burning contributions to urban aerosols in a coastal Mediterranean city. Sci Total Environ 427-428:175-190

Rogge WF, Hildemann LM, Mazurek MA, Cass GR (1998) Sources of fine organic aerosol.9. Pine, oak, and synthetic log combustion in residential fireplaces. Environ Sci Technol 32(1):13-22

Schauer JJ, Kleeman MJ, Cass GR, Simoneit BRT (2001) Measurement of emissions from air pollution sources. $3 . \mathrm{C}_{1}-\mathrm{C}_{29}$ organic compounds from fireplace combustion of wood. Environ Sci Technol 35(9):1716-1728

Schmidl C, Marr IL, Caseiro A, Kotianová P, Berner A, Bauer H, KasperGiebl A, Puxbaum H (2008) Chemical characterisation of fine particle emissions from wood stove combustion of common woods growing in mid-European Alpine regions. Atmos Environ 42:126141

Shen G, Wei S, Zhang Y, Wang R, Wang B, Li W, Shen H, Huang Y, Chen Y, Chen H, Wei W, Tao S (2012a) Emission of oxygenated 
polycyclic aromatic hydrocarbons from biomass pellet burning in a modern burner for cooking in China. Atmos Environ 60:234-237

Shen G, Tao S, Wei S, Zhang Y, Wang R, Wang B, Li W, Shen H, Huang Y, Chen Y, Chen H, Yang Y, Wang W, Wang X, Liu W, Simonich SLM (2012b) Emissions of parent, nitro, and oxygenated polycyclic aromatic hydrocarbons from residential wood combustion in rural China. Environ Sci Technol 46(15):8123-8130

Shen G, Tao S, Wei S, Zhang Y, Wang R, Wang B, Li W, Shen H, Huang Y, Yang Y, Wang W, Wang X, Simonich SLM (2012c) Retene emission from residential solid fuels in China and evaluation of retene as a unique marker for soft wood combustion. Environ Sci Technol 46(8):4666-4672

Shen G, Xue M, Wei S, Chen Y, Zhao Q, Li B, Wu H, Tao S (2013a) Influence of fuel moisture, charge size, feeding rate and air ventilation conditions on the emissions of PM, OC, EC, parent PAHs, and their derivatives from residential wood combustion. J Environ Sci (China) 25(9):1808-1816

Shen G, Wei S, Zhang Y, Wang B, Wang R, Shen H, Li W, Huang Y, Chen Y, Chen H, Tao S (2013b) Emission and size distribution of particle-bound polycyclic aromatic hydrocarbons from residential wood combustion in rural China. Biomass Bionerg 55:141-147

Shen G, Tao S, Chen Y, Zhang Y, Wei S, Xue M, Wang B, Wang R, Lu Y, Li W, Shen H, Huang Y, Chen H (2013c) Emission characteristics for polycyclic aromatic hydrocarbons from solid fuels burned in domestic stoves in rural China. Environ Sci Technol 47:1448514494

Sippula O, Hyto K, Tissari J, Raunemaa T, Jokiniemi J (2007) Effect of wood fuel on the emissions from a top-feed pellet stove. Energ Fuel 21:1151-1160

Sovadinová I, Bláha L, Janošek J, Hilscherová K, Giesy JP, Jones PD, Holoubek I (2006) Cytotoxicity and aryl hydrocarbon receptor-mediated activity of N-heterocyclic polycyclic aromatic hydrocarbons: structure-activity relationships. Environ Toxicol Chem 25(5):12911297

Telmo C, Lousada J (2011) The explained variation by lignin and extractive contents on higher heating value of wood. Biomass Bionerg 35: $1663-1667$

Tissari J, Hytönen K, Lyyränen J, Jokiniemi J (2007) A novel field measurement method for determining fine particle and gas emissions from residential wood combustion. Atmos Environ 41(37):8330 8344

Tissari J, Lyyränen J, Hytönen K, Sippula O, Tapper U, Frey A, Saarnio K, Pennanen AS, Hillamo R, Salonen RO, Hirvonen M-R, Jokiniemi J (2008) Fine particle and gaseous emissions from normal and smouldering wood combustion in a conventional masonry heater. Atmos Environ 42(34):7862-7873

Vicente ED, Duarte MA, Calvo AI, Nunes TF, Tarelho L, Alves CA (2015a) Emission of carbon monoxide, total hydrocarbons and particulate matter during wood combustion in a stove operating under distinct conditions. Fuel Process Technol 131:182-192

Vicente ED, Duarte MA, Tarelho LAC, Nunes TFV, Amato F, Querol X, Colombi C, Gianelli V, Alves CA (2015b) Particulate and gaseous emissions from the combustion of different biofuels in a pellet stove. Atmos Environ (in press)

Vu B, Alves CA, Gonçalves C, Pio C, Gonçalves F, Pereira R (2012) Mutagenicity assessment of aerosols in emissions from wood combustion in Portugal. Environ Pollut 166:172-181

Waked A, Favez O, Alleman LY, Piot C, Petit J-E, Delaunay T, Verlinden E, Golly B, Besombes J-L, Jaffrezo J-L, Leoz-Garziandia E (2014) Source apportionment of $\mathrm{PM}_{10}$ in a north-western Europe regional urban background site (Lens, France) using positive matrix factorization and including primary biogenic emissions. Atmos Chem Phys 14(7):3325-3346

White KL, Kawabata TT, Ladics GS (1994) Mechanisms of polycyclic aromatic hydrocarbon immunotoxicity. In: Dean JH, Luster MI, Munson AE, Kimer I (eds) Immunotoxicology and immunopharmacology, 2nd edn. Raven, New York, pp 123-146

Yu H (2002) Environmental carcinogenic polycyclic aromatic hydrocarbons: photochemistry and phototoxicity. J Environ Sci Health C Environ Carcinog Ecotoxicol 20:149-183

Yunker MB, Macdonald RW, Vingarzan R, Mitchell RH, Goyette D, Sylvestre S (2002) PAHs in the Fraser river basin: a critical appraisal of PAH ratios as indicators of PAH source and composition. Org Geochem 33(4):489-515

Zhang Y, Tao S, Shen H, Ma J (2009) Inhalation exposure to ambient polycyclic aromatic hydrocarbons and lung cancer risk of Chinese population. PNAS 106(50):21063-21067 